\title{
Artificial intelligence and information management in the energy transition of India: lessons from the global IT heart
}

\author{
Yash Chawla, Fumio Shimpo and Maciej M. Sokołowski
}

\begin{abstract}
Purpose - India is a fast-growing economy, that has a majority share in the global information technology industry (IT). Rapid urbanisation and modernisation in India have strained its energy sector, which is being reformed to cope. Despite being the global IT heart and having above average research output in the field of artificial intelligence (Al), India has not yet managed to leverage its benefits to the full. This study aims to address the role of Al and information management (IM) in India's energy transition to highlight the challenges and barriers to its development and use in the energy sector.
\end{abstract}

Design/methodology/approach - The study, through analysis of proposed strategies, current policies, available literature and reports, discusses the role of $A$ I and IM in the energy transition in India, highlighting the current situation and challenges.

Findings - The results show dispersed research and development incentives for IT in the Indian energy sector; however, the needed holistic top-down approach is lacking, calling for due attention in this matter. Adaptive and swift actions from policymakers towards AI and IM are warranted in India.

Practical implications - The ongoing transition of the Indian energy sector with the integration of smart technologies would result in increased access to big data. Extracting the maximum benefits from this would require a comprehensive Al and IM policy.

Social implications - The revolution in Al and robotics must be carried out in line with sustainable development goals, to support climate action and to consider privacy issues - both areas in India must be strengthened.

Originality/value - The paper offers an original discussion on certain applicable solutions regarding the energy transition of Al coming from the Global South; they are based on lessons learned from the Indian case studies presented in this study.

Keywords India, Information management, Global south, Artificial intelligence

Paper type General review

\section{Introduction}

The artificial intelligence $(\mathrm{Al})$ revolution has impacted almost every aspect of our lives, with significant advancements in areas such as the internet of things (loT), robotics, deep learning and a plethora of other Al solutions that have been used for a range of purposes (Sokołowski, 2022; Simon, 2019). It has enabled the integration of advanced information and communication systems that worked together to transform conventional systems into smart systems (Khare et al., 2020) by changing traditional urban and rural structures into smart cities and villages (Visvizi and Lytras, 2018). This happens right in front of our eyes and the expectations are substantial (Guihot et al., 2017; Sarirete et al., 2021).

This rapid improvement process (Baker, 2018) does not ignore the energy sector where emerging Al solutions are gathering momentum, and their implementation is expected to change the energy transition as technological advancement in energy production,
Yash Chawla is based at the Department of Operations Research and Business Intelligence, Wrocław University of Science and Technology, Wrocław, Poland. Fumio Shimpo is based at the Faculty of Policy Management, Keio University - Shonan Fujisawa Campus, Fujisawa, Japan. Maciej M. Sokołowski is based at the Faculty of Law and Administration, University of Warsaw, Warsaw, Poland.

Received 9 May 2021 Revised 23 October 2021 Accepted 7 November 2021

(C) Yash Chawla, Fumio Shimpo and Maciej M. Sokołowski.

Published by Emerald Publishing Limited. This article is published under the Creative Commons Attribution (CC BY 4.0) licence. Anyone may reproduce, distribute, translate and create derivative works of this article (for both commercia and non-commercial purposes), subject to full attribution to the original publication and authors. The full terms of this licence maybe seen at http://creativecommons.org/licences/by/4.0/ legalcode.

This work was supported by JST, Moonshot R\&D Grant Number JPMJMS2011. 
transmission, distribution, storage and final usage has accelerated. Apart from industry, it has an ever-increasing impact on climate and energy policies (Sokołowski, 2022). This is also true in India, where strengths such as a large young population in a vibrant democracy and a fastgrowing economy driven by the IT sector of global significance - India as the world's IT hub (Solanki and Sinha, 2017; Rao et al., 2022) - together with problems to solve, including disparities, inequalities or poverty (Gao et al., 2020, p. 5) - offers Al applications a large scope and scale (Kalyanakrishnan et al., 2018, p. 164). Furthermore, as India becomes a major international player, the way it handles the energy sector and climate change affect the whole world (Sokołowski, 2019). In June 2018, India's NITI Ayog (Planning Commission) of India, released a discussion paper on the National Strategy for Al \#AIFORALL (NITI Aayog, 2018), where the energy sector was listed as one of the focus areas for Al intervention. In addition, the updated policy document release in August 2021 built on to that discussion paper (NITI Aayog, 2021). Additionally, in a recent report by National Association of Software and Service Companies (NASSCOM), it is estimated that by 2025 Al will add a value of about $\$ 50$ to $\$ 55 \mathrm{bn}$ to the energy and industry sector of India (NASSCOM, 2021). In this context, the main objective of this article is to address the role of Al and information management (IM) in India's energy transition based on comprehensive growth and development strategies, as well as to highlight the challenges and barriers to its development and use in the energy sector related to policymaking, governance and strategy, as well as social interactions and community development, including rural/urban collaboration and smart cities/smart villages in India. The supplementary goal includes presenting certain applicable solutions regarding the Al energy transition coming from the Global South (GS); they are based on lessons learned from the Indian case studies presented in this paper.

In terms of the structure of the article, Section 2 provides a summary of the materials and methods used; Section 3 provides the background of the article in relation to the importance of IM when Al is used in the energy sector; Section 4 highlights the Indian IT industry and discusses the development of Al in India, from its inception in the 1950s to the present day; Section 5 analyses IM in the Indian energy sector and Section 6 examines AI and $\mathrm{IM}$ in this field; finally, Section 7 includes concluding remarks, focussing on the importance of this research for the GS.

\section{Material and methods}

Although there is general agreement that India's ability to develop a strong manufacturing sector over the years has been hampered by a combination of factors such as political economy, distrust of private enterprise, a lack of a well-coordinated industrial policy, stringent laws and a multitude of regulations, there is a divergence of opinion in the literature on the position of India's regulatory framework in the growth of the IT industry (Gupta and Basole, 2020, p. 345). In this debate, some argue (Kapur, 2002, p. 94) that because the Indian state's position in the IT sector has clearly differed from that in other areas, it is reasonable to assume that the state played a role in its development, for example, because of forward-looking policies (Das and Sagara, 2017, pp. 57-60), while others (Dossani, 2008) claim that the development of the industry has been because of private entrepreneurial abilities, rather than the policies of the Indian Government (Gupta and Basole, 2020, p. 345; D'Costa, 2011; Subramanian, 2014; Mukherjee, 2016).

In this light, the article is based on an examination of India's AI and IM policy and regulatory regimes, as well as related actions of different Indian stakeholders in the field of on climate and energy. A variety of materials are used to delve into the AI-IM-driven energy transition of India. The article provides valuable answers on the state of energy transition in India, providing lessons for GS, by analysing policy documents developed by the government of India, related laws and regulations, including international standards, as well as conducting a review of case studies of $\mathrm{Al}$ climate energy applications and addressing IM in the Indian energy sector. Due to its effect on India's climate action, as well as its central role in the 
government's energy vision (Sokołowski, 2019), in this article, the electricity sector is given special attention (Sokołowski, 2016).

\section{Theory}

Information, like it is in other fields, is a critical issue in the energy sector and globalisation processes, such as the spread of the internet, have made access to it easier (Żmijewski and Sokołowski, 2010, p. 13) and in the twenty-first century, consumers of generations $X, Y$ and $Z$ have become increasingly technology dependent, expecting broad access to a variety of modern devices and electronic processes to have greater autonomy and quick access to information to make informed decisions (Chawla et al., 2020, p. 3). However, while pure information is easily accessible, the increasing specialisation of human activity necessitates a strong need for the knowledge required to decode it (Żmijewski and Sokołowski, 2010, p. 13).

In this case, Al is progressively becoming the solution because of the constant development of Al techniques that are finding increasing applications in the energy sector. This includes, among other things, managing energy demand, achieving cost effectiveness, identifying conservation measures, optimising energy use and developing policy decisions or strategies to improve energy efficiency, promote renewable energy sources and reduce emissions (Azadeh et al., 2015). Many of the available Al applications are aimed at energy consumers and prosumers. Here, Al techniques are listed that are used with respect to smart meters, virtual power plants, electric vehicles, batteries or zero energy houses (Wang et al., 2020). For example, combining Al with innovations like blockchain and distributed energy would improve consumers' ability to manage energy and ensure maximum performance (Jose et al., 2020, p. 5). Furthermore, the available Al-enhanced solutions allow energy consumers and prosumers to obtain large volumes of data in a simple and efficient manner, making complex data and statistics understandable to non-experts. Thus, Al becomes a valuable tool in the hands of energy users.

Nevertheless, because they are numerical in nature, electricity consumption or reverse power flow do not provide much detail on their own. However, when these numerical statistics are collected and analysed, they become "important information" and when combined with other personal data, they can become "personal information" (Shimpo, 2020). This is crucial in the context of smart grids (Ferrag et al., 2018), which alter traditional data exchange and IM models in the electricity sector (Buchmann, 2017, p. 65) in a similar way to how the internet and e-mail changed letters and post services or how social media changed targeted advertising. In this manner, the process of smartening the grid entails some major risks, necessitating the creation and implementation of relevant legislation to safeguard the right to privacy (Florencio and Ramanathan, 2001, p. 105; Marsoof, 2008, pp. 560-561). This is especially important because this right is considered as a universal human right (Diggelmann and Cleis, 2014; Blasi Casagran, 2017, p. 228) and is viewed as fundamental in many jurisdictions around the world (Heyns and Kaguongo, 2006, p. 690; Parker, 2010). From 2017, this has also been the case in India, where the Supreme Court of India in a landmark decision (Puttaswamy v. Union of India, 2017) overruled previous judgements and specifically gave privacy the highest constitutional protection, classifying it as "an intrinsic part of the right to life and personal liberty [...] and as part of the freedoms guaranteed by [... .] the Constitution" (Luthra and Bakhru, 2019).

Regardless of the improvements brought about by the judiciary, India's privacy legislation still has significant defects. Chowdhury (2018, p. 466) distinguishes three main issues, namely, firstly, the concept of what should be considered private, and therefore, covered is exceedingly limited; secondly, the due diligence requirement is insufficient, allowing intermediaries to avoid responsibility even in the event of data breaches and thirdly, a contractual consent regime cannot safeguard data protection. Despite the fact that these issues, in principle, impede the position of Al users by leaving out a vast amount of data 
created by private activities and exposing users to a variety of violations such as surveillance, profiling and data theft (Chowdhury, 2018, p. 466), Al in India is rapidly developing in practice, although this has not always been the case in the past.

\section{Development of IT and artificial intelligence in India}

In 2020, the size of the Indian information technology market was nearly US\$200bn, with almost $75 \%$ being exported (IBEF, 2021). It has come a long way since the beginning of the country's computerisation in the 1950s and 1960s, when the first UK-made digital computer named Hollerith Electronic Digital Computer-2M (HEDC-2M) was established in 1955. Followed by the completion of the first indigenously built computer TIFRAC in 1956 (Rajaraman, 2015, p. 26). India has a long history of developing policy frameworks to address the advancement of emerging technologies, including computing. In 1963, Prime Minister Jawaharlal Nehru established the Electronics Committee (Subramanian, 2014, p. 20) and in 1965, India began replacing mechanical tabulators with computers (Bhatt, 2004, p. 92). Four years later, the first India-made 12-bit real-time computer (Trombay Digital Computer) was commissioned (1969) and in 1970, under Prime Minister Indira Gandhi, the Department of Electronics (DoE) and Electronic Commission (EC) replaced the Electronics Committee (Subramanian, 2014, p. 21). The DoE and the EC became the main governmental regulatory bodies in charge of overseeing all aspects of computer development, introducing strict import rules for electronics and computers (Subramanian, 2014, p. 21).

The strict regulatory approach to foreign companies (which led to International Business Machines Corporation (IBM) leaving India) persisted mainly until the 1980s, when Rajiv Gandhi declared a liberalised approach as soon as he became Prime Minister (Rajaraman, 2015, p. 28). This included a significant "New Computer Policy" of 1984 (Kumar, 1987; Karki and Cameron, 1995, p. 95), as well as a liberalised software policy (1986) that provided additional export incentives (Rajaraman, 2015, p. 28). Apart from earlier steps in minicomputers, these liberalisation policies of 1984-1986 had a great effect, resulting in a $50 \%$ price drop. This led to the rapid growth of computer use, especially because of its affordability, the entry of several multinational corporations that collaborated with Indian companies and the creation of the software export industry (Rajaraman, 2015, pp. 29-30).

As a result, until the year 2000, the software industry in India was largely comprising service providers for global clients. Following Y2K (Millennium bug) and the first wave of global internet or dot-com era, Indian companies effectively leveraged their infrastructure and were able to deliver services to global enterprises remotely (Jalote and Natarajan, 2019, pp. 65-65). Over the next two decades, up to 2020, Indian IT captured more than $55 \%$ of the global market share in the IT industry (\#1 sourcing destination in the world) and is expected to be valued at US $\$ 350$ bn by 2025 (Invest India, 2021). Moreover, India currently houses around $75 \%$ of the global digital talent, becoming a global digital capabilities hub (Invest India, 2021). The current government policies for the IT sector hugely support growth drivers such as skill development and R\&D, National Optical Fibre Network, Digital India campaign, StartUp revolution, Al and Atmanirbhar Bharat, with provisions for $100 \%$ Foreign Direct Investment (Invest India, 2021). Although recently the Indian IT sector has suffered as a result of the COVID-19 pandemic, as several companies have seen a drop in revenue due to the global cut-offs on technology spending, there are some IT-related businesses that are more immune to the impact of the coronavirus, such as telecommunications (Kumar and Kumara, 2021, p. 2556). Furthermore, while the aftermath of COVID-19 would undoubtedly benefit many online platforms and start-ups involved in offering online services, this would not be feasible without information communication technology; therefore, this will contribute to the global expansion of the IT sector with India as its part (Joshi, 2021, p. 46).

In the post-pandemic world, there is also a lot of room for Al to be used. In India, this area has a long history of development (though with varying outcomes). Its origins may be traced 
back to the 1960s, when Professor H.N. Mahabala began his work, and later efforts of the knowledge-based computing systems back by the United Nations Development Programme. Since then, India has seemingly been dormant and the US became a pioneer in the development of Al; however, China soon caught up quickly (Simon, 2019, pp. 223-224) and has the potential to be a global leader of Al by 2030 (Elias, 2020) - an international full-fledged race for Al breakthrough technology has already begun (Feijóo et al., 2020). Despite having more than the threshold level of research activities, India was classified in the third group out of four as a country with moderate foundations to take advantage of the economic benefits of $\mathrm{Al}$ (Bughin et al., 2018, pp. 34-45). At present, India has ranked 6th in Stanford's Global Al Vibrancy Ranking and aces the "Inclusion" parameter, has about 500,000 workers employed in Al-related roles by the industry, ranks 8th in the world in Al patent filing, ranks 4th in the world in scholarly articles on $\mathrm{Al}$, has a growing penetration of $\mathrm{Al}$ in start-ups and enterprises with more than $50 \%$ and $45 \%$ of them using Al in some form or another, respectively (NASSCOM, 2021).

For the Indian economy, AI has the potential to deliver a rise in annual growth rate by 1.3 percentage points by 2035 , which is the equivalent of $15 \%$ of the current Indian gross domestic product (Elias, 2020). In a shorter term, Al also has the potential to add a value of almost \$490bn across 9 major sectors in India, including consumer goods and retail; telecom, media and IT; auto manufacturing and Assembly; agriculture; energy and industrials; public sector; banking and insurance; transport and logistics and healthcare (NASSCOM, 2021). Furthermore, Al holds promise as a catalyst to accelerate progress and address traditional barriers such as weak infrastructure and bureaucracy, with effective applications in almost every sector ranging from finance, health care, law enforcement, transportation, agriculture, environmental protection or telecommunications (Kalyanakrishnan et al., 2018, p. 165; Curwen and Whalley, 2017).

This has served as a wake-up call for policymakers in India, and in 2018 a discussion document on the National AI Strategy (NITI Aayog, 2018) was released, which forms the basis for the National Al Programme, with a unique brand \#AlforAll. The strategy focusses on five sectors, as shown in Table 1, addressing some sectors as also described by Kalyanakrishnan et al. (2018).

The strategy also recognised some of the key challenges India would need to address for the success of \#AlforAll. They include a comparatively small number of broad-based expertise in Al research and application; lack of enabling data ecosystems; high costs associated with acquiring resources, lack of awareness and latest knowledge locally; lack of formal regulations for data anonymisation and lack of collaborative approach towards adoption and application. To overcome these challenges and address India's Al aspirations, the establishment of the Centre for Research Excellence and the International Centres for Transformational Al has been proposed in the strategy document. However, addressing the challenges and formulating $\mathrm{Al}$ policies would require a comprehensive improvement in the Al strategy (Chatterjee, 2020). Especially for the energy sector in India, which is currently highly strained, especially in terms of distribution (IEEFA India, 2020), and

\section{Table 1 Five sectors focussed on, in the 2018 Indian strategy for AI (NITI Aayog, 2018)}

Sector

Health care

Agriculture

Education

Smart cities and

infrastructure

Smart mobility and

transformation
Expected outcome

Increase in affordability and access to quality health care

Increase in agricultural produce and framers' earnings, along with reduction in wastage of resources Increase in access and improvement in the quality of education Efficient and connectivity for the growing urban population

Improvement in prevailing traffic and congestion conditions and implementation of smarter and safer transportation modes 
in the development of smart cities and infrastructure, the strategy document does not address this issue. It only briefly introduces some potential cases from the energy sector, which is surprising as studies have found how Al can positively influence the energy sector (Akcin et al., 2016).

\section{Information management in the energy sector of India}

Although there are more energy sector data available in India than ever before, especially through a combination of websites and portals, there are still challenges in identifying and acquiring them, as well as with accuracy that differs between public data holders (Ali and Tongia, 2018). For example, apart from policy and infrastructure concerns, a major impediment to the implementation of the Jawaharlal Nehru National Solar Mission is the lack of solar data, including suitable mapped land areas for solar power with possible projections at the local level (because data on solar potential are only available for sites with measuring instruments), while accurate and detailed knowledge of the solar radiation characteristics of the location (in various forms such as models or maps) is needed for proper sizing of solar energy systems (Anwar and Deshmukh, 2018, pp. 63-64; Daus et al., 2018). Although the India Meteorological Department is the national institution responsible for measuring and archiving daily values of meteorological parameters, there are very few stations for measuring and collecting solar radiation data (Soni et al., 2012), while a statewide assessment would be beneficial (Anwar and Deshmukh, 2018, pp. 63-64).

Moreover, Srivastav (2021, p. 158) emphasises that many Indians are unaware of the negative impact of thermal power plants in their cities and that if they were more informed about the health impacts of these installations, there would be widespread public support for solar and wind power, but this may not be in the interests of mining and other stakeholders of conventional energy. This is due to the lack of IM, including data collection and communication with consumers. To meet with further growth in demand and to update and strengthen the Indian transmission and distribution of grids, the government of India launched a National Smart Grid Mission (IEA, 2020, p. 176). This will result in the transition of India's energy sector towards modernisation, as well as the installation of smart devices to increase consumer participation, resulting in an increase in the number of prosumers. In April 2021, the NITI Ayog of India launched the India Energy Dashboard (version 2.0) (www. niti.gov.in/edm/), with the aim of providing single-window access to the energy data along with interesting data visualisations. To encourage more research and use of these data for development, the portal is publicly available with free access and does not require any login credentials. The portal provides Application Programming Interface (API) linked data from various government initiatives such as Saubhagya, Unnat Jyoti by Affordable LEDs for All (UJALA), Payment Ratification and Analysis in Power Procurement for bringing Transparency in Invoicing of Generators (PRAAPTI) and Vidyut PRAVAH (NITI Ayog IED, 2021). Certainly, India is heading in the direction of increasing data being generated and improvement in IM systems to leverage its benefits through Al applications would be warranted for a densely populated country like India.

\section{Artificial intelligence in India to improve energy information management}

India prioritises energy issues, which are an important part of the government's vision for the future, as it has been identified as a key driver of the country's economic development (Sokołowski, 2019, p. 63). Different energy technologies play a crucial role in this growth. Among them, smart grid solutions have been implemented in the Indian electricity sector since the early 2010s. For instance, in 2012, 14 smart grid pilot projects were chosen for implementation by state distribution utilities and in 2015, the National Smart Grid Mission was launched, with the first phase offering a 100\% budget outlay (INR 300m) for customer engagement activities (Chawla et al., 2020, p. 2). As of March 2021, India has 11 smart grid pilot projects and 5 others are being implemented (Ministry of Power, 2021). 
These steps can be supported by a variety of modern solutions that use Al techniques. For example, the Indian Solar Irradiance Operational System (INSIOS), developed by Masoom et al. (2020) for the needs of photovoltaics (PV) in India, performs multivariate studies of the interactions between radiation, clouds and aerosols in the atmosphere, as well as generating real-time solar irradiance maps based on real-time satellite inputs and aerosol forecasts. Artificial neural network models are used for the prediction of solar energy potential in Indian states such as Andhra Pradesh and Telangana, improving the unavailability of solar data at the local level (Anwar and Deshmukh, 2018; Makade et al., 2021). These types of models have a wide variety of applications in renewable energy, including the ability to predict wind speed (Parmar et al., 2017) or the potential to determine the optimal renewable energy mix to assist policymakers in India's future energy planning (Gupta et al., 2021). Furthermore, due to the limitations of Indian metrological centres, Al solutions that include artificial neural network prediction capacity and adaptive neuro fuzzy inference systems can be used to find the optimal sizing and tilting of PV installations and battery systems for remote locations in India, without reference to metrological data (Jeyaprabha and Selvakumar, 2015).

Large-scale photovoltaic plants are commonly seen in torrid regions such as Rajasthan in India (Pandey et al., 2012); however, these plants must contend with habitat factors such as high dust concentration that require maintenance services to boost PV installation performance (Parashar and Parashar, 2018, p. 4925; Liu et al., 2021; Kasim et al., 2021). In this process, robotic cleaners provide effective assistance that can be enhanced by using machine learning algorithms and Al techniques such as artificial neural networks and genetic algorithms to design cleaners' performance by measuring sensor data and providing various information such as the battery's profitable life by applying prognostic algorithms to its charging (Parashar and Parashar, 2018, p. 4926).

In addition to remote regions, Indian cities require Al assistance (Baruah et al., 2021). Here, Al techniques are used to improve air quality and reduce emissions. This includes, for example, models based on artificial neural networks developed for public health-oriented air quality forecasting and used at popular sites such as the Taj Mahal (Mishra and Goyal, 2015). Apart from air quality, there are other reportedly several issues such as heavy traffic congestion and increasingly rising energy costs as a result of current traffic management (Agarwal et al., 2015, p. 21). By providing information on traffic congestion, air quality and energy used, systems using Al techniques may significantly improve this situation (Agarwal et al., 2015, p. 21). According to the findings of a case study conducted in Kerala (7.5 million domestic consumers), load-shifting operations under the dynamic shifting programme result in an average of $8 \%$ additional annual household electricity bill savings and an $18 \%$ increase in the usage of energy produced from renewable sources at the consumer level (Rajeev and Ashok, 2015).

Furthermore, many of the available solutions aimed at improving energy efficiency using Al techniques are provided by multinational corporations based in India, such as Wipro or Tata Consultancy Services (Reddy and Raghavaiah, 2021). This includes, for example, automated lighting systems that use a variety of sensors in conjunction with the fuzzy logic concept to provide automated control for illumination (Mahajan, 2015), as happens in Pune in Maharashtra, which aims to install energy-efficient street lights that can be operated remotely using Supervisory Control and Data Acquisition systems under which the Pune Street Light Project (NITI Aayog, 2018, p. 39). Mahindra Teqo is another example of an Al application for electricity generation, specifically making production in solar sources cleaner. The team at Mahindra Teqo claims that their Al algorithms, if applied to the installed solar energy capacity of 40 gigawatts in India, can result in savings of up to $\$ 70 \mathrm{~m}$ annually (Teqo, 2021). This becomes even more important as India aims to grow its solar energy production capacity to 100 gigawatts by 2022 (India SDG Action, 2021).

India's Al policy also concentrates heavily on "Responsible" Al for All (NITI Ayog, 2021). Due thought is being given in the development of policy to ensure that the established 
frameworks result in accurate, safe and reliable deployment. Some of the major considerations outlined in the most recent policy documents (NITI Ayog, 2021) are, namely, consistency across stakeholders, accountability of Al decisions, privacy risks, security risks, impact on jobs and malicious use of $\mathrm{Al}$ for psychological profiling or false propaganda. There have been several instances in which India's justice system has benchmarked the prevailing morality in India with the principle of constitutional morality (SCl, 2018). Because of this, the Al policies in India naturally adhere with the principles identified by the international organisations such as the Global Partnership of Al (https:// gpai.ai/projects/responsible-ai/). This approach is crucial for a safe and secure deployment of $\mathrm{Al}$ in the energy sector, as there have already been several instances in different parts of the world where breaches have been detected (Cytomic, 2021).

\section{Conclusions}

India has a long history of creating policy structures to counter new technological advances. As the growth of the IT industry has shown, a strict regulatory approach hampered the potential for improving India's economy's innovativeness, while a more flexible approach, with active state involvement (like a day-watchman type), was beneficial (Sokołowski, 2020a, 2020b). It is a valuable lesson from the global IT heart of the GS, which is India.

In this light, this model should be replicated in the implementation of Al for the needs of the energy sector. However, the Government of India must first recognise the potential of $\mathrm{Al}$ in the energy sector. Although there are various dispersed research and development incentives for $\mathrm{Al}$ in the energy sector run by different actors, a holistic top-down approach is needed, with energy being one of the sectors targeted by the Indian Al Strategy. Actions such as the National Smart Grid Mission or the Smart Cities and Infrastructure or India Energy Dashboards should be commended; however, a more comprehensive attitude is needed, as India's energy sector, including electricity, faces numerous challenges such as data collection and communication with energy customers.

Consequently, such a holistic, strategy-driven approach would be advantageous for the wider implementation of Al in India, which could improve the role of energy consumers by providing them with much needed knowledge and enabling them to become smart energy users; this involves not only prices but also environmental impacts of energy use related to all aspects of climate action including renewable energy, energy efficiency and emissions reduction. As a result, India needs a policy framework for Al and IM in the energy transition.

Due to the significant progress made over the years towards their development, previously ground-breaking solutions in AI, IOT, robotics and deep learning have become everyday items, finding applications in a variety of branches and industries, including the energy sector. Emerging technologies such as Al and loT are rapidly improving and their application in the energy sector is expected to shift the energy transition as technological progress related to all stages of energy usage, ranging from production to consumption, has accelerated. Furthermore, autonomous robots with Al will become more common in the future and are expected to be particularly useful in places where human operation is difficult, such as mountainous areas and deep seas, as well as in harsh environments (Wong et al., 2018). We anticipate that robots will be widely used in the maintenance and management of power plants and different Al techniques can be used more widely in the energy sector. This is also true for India, with all the opportunities and challenges that robotics and Al bring.

Two major issues emerge among them. First and foremost, the Al and robotics revolution must be carried out in accordance with sustainable development goals (Ryan and Stahl, 2021, p. 75). In this way, the process must support, not hinder, climate action. This is especially important in terms of the development of robotics and batteries as well as the 
energy used in implementing various Al solutions. The Al revolution must be a green revolution, in which Al techniques and robotics use less energy (instead of more) in an intelligent manner, with a preference for renewable energy. Thus, it is critical to define clear criteria and the highest standards for energy efficiency in Al and robotics, as well as to combine the growth of renewables with advancements in Al and robotics. This is also the case for India, which should focus on developing green Al rather than "developing Al". Such Al is expected to be a priority as a result of global climate policy agreements and globally announced energy transformations, as well as the vision of climate neutrality. The sooner India becomes more involved in the development of this area of Al, the better for the Indian economy and society, as green Al can contribute to India's modernisation, putting it on the path to clean energy transformation and climate neutrality.

Secondly, privacy issues are extremely important. In conducting the energy transition enhanced by smart energy solutions, Al techniques collect a variety of information, including data from autonomous vehicles and robots. The vast volume of data generated as a result of these new technologies would create problems that current Al technologies would not be able to address. The same can be said for the laws that are currently in place. As a result, it will be critical to assess what problems will arise as a result of the increased use of Al solutions and autonomous devices such as robots in the energy sector. This also necessitates an open discussion of any countermeasures that may be required as $\mathrm{Al}$ develops in India. We must act quickly and wisely. "There is no hand to catch time", an Indian proverb says.

\section{References}

Agarwal, P.K., Gurjar, J., Agarwal, A.K. and Birla, R. (2015), "Application of artificial intelligence for development of intelligent transport system in smart cities", Journal of Traffic and Transportation Engineering, Vol. 1 No. 1, pp. 20-30.

Akcin, M., Kaygusuz, A., Karabiber, A., Alagoz, S., Alagoz, B.B. and Keles, C. (2016), "Opportunities for energy efficiency in smart cities", 2016 4th International Istanbul Smart Grid Congress and Fair (ICSG), IEEE, pp. 1-5.

Ali, S. and Tongia, R. (2018), "Energy sector data: suggestions for improving data quality and usability", No. 092018, Brookings India, available at: https://think-asia.org/bitstream/handle/11540/8879/ Discussion-note-final1.pdf?sequence=1 (accessed 8 May 2021).

Anwar, K. and Deshmukh, S. (2018), "Use of artificial neural networks for prediction of solar energy potential in Southern states of India", 2018 2nd International Conference on Green Energy and Applications (ICGEA), IEEE, pp. 63-68.

Azadeh, A., Narimani, A. and Nazari, T. (2015), "Estimating household electricity consumption by environmental consciousness", International Journal of Productivity and Quality Management, Vol. 15 No. 1, pp. 1-19.

Baker, J.J. (2018), "2018: a legal research odyssey: artificial intelligence as disruptor", Law Library Journal, Vol. 110 No. 1, pp. 5-30.

Baruah, A., Basu, M. and Amuley, D. (2021), "Modeling of an autonomous hybrid renewable energy system for electrification of a township: a case study for Sikkim, India", Renewable and Sustainable Energy Reviews, Vol. 135, p. 110158.

Bhatt, R.M. (2004), "Growth of computing technology for education in India", in Lee, J.A. (Ed.), IFIP International Conference on the History of Computing, Kluwer Academic Publishers, Boston, MA, pp. 91-102.

Blasi Casagran, C. (2017), Global Data Protection in the Field of Law Enforcement: An EU Perspective, Routledge, Abingdon - New York, NY.

Buchmann, M. (2017), "Governance of data and information management in smart distribution grids: increase efficiency by balancing coordination and competition", Utilities Policy, Vol. 44, pp. 63-72.

Bughin, J., Seong, J., Manyika, J., Chui, M. and Joshi, R. (2018), Notes from the Al Frontier: modeling the Impact of Al on the World Economy, McKinsey Global Institute. 
Chatterjee, S. (2020), "Al strategy of India: policy framework, adoption challenges and actions for government", Transforming Government: People, Process and Policy, Vol. 14 No. 5.

Chawla, Y., Kowalska-Pyzalska, A. and Skowrońska-Szmer, A. (2020), "Perspectives of smart meters' roll-out in India: an empirical analysis of consumers' awareness and preferences", Energy Policy, Vol. 146, p. 111798.

Chowdhury, N. (2018), "Privacy and citizenship in India: exploring constitutional morality and data privacy", NUJS Law Review, Vol. 11 No. 3, pp. 421-468.

Curwen, P. and Whalley, J. (2017), "A tale of many auctions: mobile communications in India struggle to overcome a dysfunctional structure", Digital Policy, Regulation and Governance, Vol. 19 No. 3, pp. 225-250.

Cytomic (2021), "Details of more than 270,000 customers leaked in electricity firm data breach", Cytomic, January 2021, available at: www.cytomic.ai/enterprise/customers-electricity-firm-data-breach/ (accessed 2 October 2021).

D'Costa, A.P. (2011), "Geography, uneven development and distributive justice: the political economy of IT growth in India", Cambridge Journal of Regions, Economy and Society, Vol. 4 No. 2, pp. 237-251.

Das, K. and Sagara, H. (2017), "State and the IT industry in India", Economic \& Political Weekly, Vol. 52 No. 41, pp. 56-64.

Daus, Y., Kharchenko, V. and Yudaev, I.V. (2018), "Solar radiation intensity data as basis for predicting functioning modes of solar power plants", in Kharchenko, V. and Vasant, P. (Eds), Handbook of Research on Renewable Energy and Electric Resources for Sustainable Rural Development, IGI Global, Hershey, PA, pp. 283-309.

Diggelmann, O. and Cleis, M.N. (2014), "How the right to privacy became a human right", Human Rights Law Review, Vol. 14 No. 3, pp. 441-458.

Dossani, R. (2008), India Arriving: How This Economic Powerhouse is Redefining Global Business, AMACOM, New York, NY.

Elias, J. (2020), "India's Al journey: the story so far", Website, available at: https://indiaai.gov.in/article/ india-s-ai-journey-the-story-so-far (accessed 8 May 2021).

Feijóo, C., Kwon, Y., Bauer, J.M., Bohlin, E., Howell, B., Jain, R., Potgieter, P., et al. (2020), "Harnessing artificial intelligence (AI) to increase wellbeing for all: the case for a new technology diplomacy", Telecommunications Policy, Vol. 44 No. 6, p. 101988.

Ferrag, M.A., Maglaras, L.A., Janicke, H., Jiang, J. and Shu, L. (2018), "A systematic review of data protection and privacy preservation schemes for smart grid communications", Sustainable Cities and Society, Vol. 38, pp. 806-835.

Florencio, P.S. and Ramanathan, E.D. (2001), "Secret code: the need for enhanced privacy protections in the United States and Canada to prevent employment discrimination based on genetic and health information", Osgoode Hall Law Journal, Vol. 39 No. 1, pp. 77-116.

Gao, J., Cheng, S.-L., Baikady, R. and Govindappa, L. (2020), "Introduction: globalization, economic reform and social welfare in India and China", in Gao, J., Baikady, R., Govindappa, L. and Cheng, S.-L. (Eds), Social Welfare in India and China: A Comparative Perspective, Palgrave Macmillan, Singapore, pp. 1-17.

Guihot, M., Matthew, A.F. and Suzor, N.P. (2017), "Nudging robots: innovative solutions to regulate artificial intelligence", Vanderbilt Journal of Entertainment and Technology Law, Vol. 20 No. 2, pp. 385-456.

Gupta, N., Agarwal, M., Garg, P. and Bansal, M. (2021), "Revenue optimization modeling for renewable energy resource mix for sustainable development", Journal of Revenue and Pricing Management, Vol. 20 No. 2, pp. 108-115.

Gupta, G. and Basole, A. (2020), "India's information technology industry: prospects for growth and role in structural transformation", DECISION, Vol. 47 No. 4, pp. 341-361.

Heyns, C. and Kaguongo, W. (2006), "Constitutional human rights law in Africa", South African Journal on Human Rights, Vol. 22 No. 4, pp. 673-717.

IBEF (2021), "Infographics on IT industry \& BPM in India", available at: www.ibef.org/industry/informationtechnology-india/infographic (accessed 8 May 2021). 
IEA (2020), "India 2020 energy policy review”, International Energy Agency, available at: https://niti. gov.in/sites/default/files/2020-01/IEA-India\%202020-In-depth-EnergyPolicy_0.pdf (accessed 8 May 2021).

IEEFA India (2020), "IEEFA India: distribution the weakest link in India's power sector", Institute for Energy Economics \& Financial Analysis, 16 March, available at: https://ieefa.org/ieefa-india-distribution-theweakest-link-in-indias-power-sector/ (accessed 8 May 2021).

India SDG Action (2021), "India plans to produce 175 GW of renewable energy by 2022", Ministry of New and Renewable Energy, Government of India, available at: https://sustainabledevelopment.un.org/ partnership/?p=34566 (accessed 2 October 2021).

Invest India (2021), "IT industry in India - Investment opportunities, FDI \& growth", available at: https:// www.investindia.gov.in/sector/it-bpm (accessed 8 May 2021).

Jalote, P. and Natarajan, P. (2019), "The growth and evolution of India's software industry", Communications of the ACM, Vol. 62 No. 11, pp. 64-69.

Jeyaprabha, S.B. and Selvakumar, A.I. (2015), "Optimal sizing of photovoltaic/battery/diesel based hybrid system and optimal tilting of solar array using the artificial intelligence for remote houses in India", Energy and Buildings, Vol. 96, pp. 40-52.

Jose, R., Panigrahi, S.K., Patil, R.A., Fernando, Y. and Ramakrishna, S. (2020), "Artificial intelligencedriven circular economy as a key enabler for sustainable energy management", Materials Circular Economy, Vol. 2 No. 1, pp. 1-7.

Joshi, S. (2021), "Rising importance of remote learning in India in the wake of COVID-19: issues, challenges and way forward", world journal of science", World Journal of Science, Technology and Sustainable Development, Vol. 18 No. 1, pp. 44-63.

Kalyanakrishnan, S., Panicker, R.A., Natarajan, S. and Rao, S. (2018), "Opportunities and challenges for artificial intelligence in India", Proceedings of the 2018 AAAl/ACM Conference on Al, Ethics, and Society, pp. $164-170$

Kapur, D. (2002), "The causes and consequences of India's IT boom", India Review, Vol. 1 No. 2 , pp. 91-110.

Karki, R. and Cameron, A. (1995), "Designing policy initiatives in emerging economic environment: case of Indian computer hardware industry", Economic and Political Weekly, pp. M, pp. 94M-97.

Kasim, N.K., Obaid, N.M., Abood, H.G., Mahdi, R.A. and Humada, A.M. (2021), "Experimental study for the effect of dust cleaning on the performance of grid-tied photovoltaic solar systems", International Journal of Electrical \& Computer Engineering (2088-8708), Vol. 11 No. 1.

Khare, V., Khare, C., Nema, S. and Baredar, P. (2020), "Renewable energy system paradigm change from trending technology: a review", International Journal of Sustainable Energy, pp. 1-22.

Kumar, A. (1987), "Software policy: where are we headed?", Economic and Political Weekly, Vol. 22 No. 7, pp. 290-294.

Kumar, M.P. and Kumara, N.M. (2021), "Market capitalization: pre and post COVID-19 analysis", Materials Today: Proceedings, Vol. 37, pp. 2553-2557.

Liu, X., Yue, S., Lu, L. and Li, J. (2021), "Investigation of the dust scaling behaviour on solar photovoltaic panels", Journal of Cleaner Production, Vol. 295, p. 126391.

Luthra, S.K. and Bakhru, V. (2019), "Publicity rights and the right to privacy in India", National Law School of India Review, Vol. 31 No. 1, pp. 125-148.

Mahajan, R. (2015), "Application of fuzzy logic in automated lighting system in a university: a case study", International Journal of Engineering and Manufacturing, Vol. 5 No. 3, pp. 11-19.

Makade, R.G., Chakrabarti, S. and Jamil, B. (2021), "Development of global solar radiation models: a comprehensive review and statistical analysis for indian regions", Journal of Cleaner Production, Vol. 293, p. 126208.

Masoom, A., Kosmopoulos, P., Bansal, A. and Kazadzis, S. (2020), "Solar energy estimations in India using remote sensing technologies and validation with sun photometers in urban areas", Remote Sensing, Vol. 12 No. 2, p. 254.

Marsoof, A. (2008), "The right to privacy in the information era: a South Asian perspective", SCRIPTed-A Journal of Law, Technology \& Society, Vol. 5 No. 3, pp. 553-574. 
Ministry of Power (2021), "Status of NSGM smart grid projects; status of smart grid pilot projects (under IPDS)", available at: www.nsgm.gov.in/sites/default/files/SG-Projects-Status-March-2021.pdf (accessed 8 May 2021).

Mishra, D. and Goyal, P. (2015), "Development of artificial intelligence based NO2 forecasting models at Taj Mahal, Agra”, Atmospheric Pollution Research, Vol. 6 No. 1, pp. 99-106.

Mukherjee, D. (2016), "IT services in the Indian economy: an analysis and comparison with selected countries", Journal of South Asian Development, Vol. 11 No. 2, pp. 203-223.

NASSCOM (2021), "Al gamechangers: accelerating India with innovation”, available at: https://digitalindia. gov.in/writereaddata/files/NASSCOM\%20Al\%20gamechangers\%20compendium\%20-\%202021\%20edition. pdf (accessed 2 October 2021).

NITI Aayog (2018), "Discussion paper: national strategy for artificial intelligence", available at: https://niti. gov.in/writereaddata/files/document_publication/NationalStrategy-for-Al-Discussion-Paper.pdf (accessed 8 May 2021).

NITI Aayog (2021), "Responsible AI \#AIForAll - Approach document for India: part 2 - Operationalizing principles for responsible Al, August 2021", available at: www.niti.gov.in/sites/default/files/2021-08/ Part2-Responsible-Al-12082021.pdf (accessed 2 October 2021).

NITI Ayog IED (2021), "Launch of India energy dashboards (version 2.0) by NITI aayog, niti ayog, April 2021", available at: https://pib.gov.in/PressReleasePage.aspx?PRID=1711204 (accessed 2 October 2021).

Pandey, S., Singh, V.S., Gangwar, N.P., Vijayvergia, M.M., Prakash, C. and Pandey, D.N. (2012), "Determinants of success for promoting solar energy in Rajasthan, India", Renewable and Sustainable Energy Reviews, Vol. 16 No. 6, pp. 3593-3598.

Parashar, S. and Parashar, R. (2018), "Artificial intelligence in robotic cleaners - a new revolutionary paradigm for India's most ambitious solar energy program", Proceedings of the 12th INDIACom, pp. 4924-4928.

Parker, T. (2010), "Are we protected? The adequacy of existing legal frameworks for protecting privacy in the biometric age", in Kumar, A. and Zhang, D. (Eds), Ethics and Policy of Biometrics: Third International Conference on Ethics and Policy of Biometrics and International Data Sharing, Springer, Berlin, pp. 40-46.

Parmar, R., Shah, M. and Shah, M.G. (2017), "A comparative study on different ANN techniques in wind speed forecasting for generation of electricity", IOSR Journal of Electrical and Electronics Engineering, Vol. 12 No. 01, pp. 19-26.

Puttaswamy v. Union of India (2017), "10 scc 1 (2017)".

Rajaraman, V. (2015), "History of computing in India: 1955-2010", IEEE Annals of the History of Computing, Vol. 37 No. 1, pp. 24-35.

Rajeev, T. and Ashok, S. (2015), "Dynamic load-shifting program based on a cloud computing framework to support the integration of renewable energy sources", Applied Energy, Vol. 146, pp. 141-149.

Rao, M.S., Podile, V., Navvula, D. and Samishetti, B. (2022), "A study on artificial intelligence for economic renaissance in India", in Kumar, P., Obaid, A.J., Cengiz, K., Khanna, A. and Balas, V.E. (Eds), A Fusion of Artificial Intelligence and Internet of Things for Emerging Cyber Systems, Springer, Cham, pp. 395-407.

Reddy, B.K. and Raghavaiah, N.V. (2021), "Smart energy-efficient techniques for large-scale process industries", in Tripathi, S.L., Singh, D.K., Padmanaban, S. and Raja, P. (Eds), Design and Development of Efficient Energy Systems, John Wiley \& Sons, Chichester, pp. 67-100.

Ryan, M. and Stahl, B.C. (2021), "Artificial intelligence ethics guidelines for developers and users: clarifying their content and normative implications", Journal of Information, Communication and Ethics in Society, Vol. 19 No. 1, pp. 61-86.

Sarirete, A., Balfagih, Z., Brahimi, T., Lytras, M.D. and Visvizi, A. (2021), Artificial Intelligence and Machine Learning Research: Towards Digital Transformation at a Global Scale, Springer.

SCI (2018), "In the supreme court of India, criminal original jurisdiction, WRIT petition (criminal) no. 76 of 2016", available at: https://main.sci.gov.in/supremecourt/2016/14961/14961_2016_Judgement_06-Sep2018. pdf (accessed 2 October 2021).

Shimpo, F. (2020), "The importance of 'smooth' data usage and the protection of privacy in the age of Al, IoT and autonomous robots", Global Privacy Law Review, Vol. 1 No. 1, pp. 49-54. 
Simon, J.P. (2019), "Artificial intelligence: scope, players, markets and geography, digital policy”, Digital Policy, Regulation and Governance, Vol. 21 No. 3, pp. 208-237.

Sokołowski, M.M. (2016), Regulation in the European Electricity Sector, Routledge, Abingdon - New York, NY.

Sokołowski, M.M. (2019), "When black meets green: a review of the four pillars of india's energy policy", Energy Policy, Vol. 130, pp. 60-68.

Sokołowski, M.M. (2020a), "Regulation in the COVID-19 pandemic and post-pandemic times: daywatchman tackling the novel coronavirus", Transforming Government: People, Process and Policy, Vol. 15 No. 2, pp. 206-218.

Sokołowski, M.M. (2020b), "Balancing energy regulation: a day-watchman approach", in: Grzeszczak, R. (Ed.), Economic Freedom and Market Regulation: In Search of Proper Balance, Nomos, Baden-Baden, pp. 167-186.

Sokołowski, M.M. (2022), "Al and climate-energy policies of the EU and Japan", in Bielicki, D. (Ed.), Regulating Artificial Intelligence in Industry, Routledge, Abingdon- New York, NY, pp. 138-155.

Solanki, D.K. and Sinha, K. (2017), "Innovation and development in information technology in India: specific to software industry", Journal of Technology Management for Growing Economies, Vol. 8 No. 2, pp. 129-144

Soni, V.K., Pandithurai, G. and Pai, D.S. (2012), "Evaluation of long-term changes of solar radiation in India", International Journal of Climatology, Vol. 32 No. 4, pp. 540-551.

Srivastav, A. (2021), Energy Dynamics and Climate Mitigation: An Indian Perspective, Springer Nature.

Subramanian, R. (2014), "Technology policy and national identity: the microcomputer comes to India", IEEE Annals of the History of Computing, Vol. 36 No. 3, pp. 19-29.

Teqo (2021), "Making solar power 'cleaner' with Mahindra Teqo", available at: www.mahindrateqo.com/ portfolio/making-solar-power-cleaner-with-mahindra-teqo/ (accessed 3 October 2021).

Visvizi, A. and Lytras, M.D. (2018), "It's not a fad: smart cities and smart villages research in European and global contexts", Sustainability, Vol. 10 No. 8, pp. 2727.

Wang, Z., Ogbodo, M., Huang, H., Qiu, C., Hisada, M. and Abdallah, A.B. (2020), "AEBIS: Al-enabled blockchain-based electric vehicle integration system for power management in smart grid platform", IEEE Access, IEEE, Vol. 8.

Wong, C., Yang, E., Yan, X.-T. and Gu, D. (2018), "Autonomous robots for harsh environments: a holistic overview of current solutions and ongoing challenges", Systems Science \& Control Engineering, Vol. 6 No. 1, pp. 213-219

Żmijewski, K. and Sokołowski, M.M. (2010), "Identyfikacja barier i problemów związanych z polską energetyką odnawialną jako wybór relewantnej informacji dla rządu, społeczeństwa i gospodarki [identification of barriers and problems related to the polish renewable energy industry as a selection of relevant information for the government, society and economy]", in Sitek, B. and Trzaskalik, R. (Eds), Zarządzanie Informacja i Energią w Systemie Bezpieczeństwa Unii Europejskiej [Information and Energy Management in the European Union's Security System], WSGE, Józefów, pp. 13-28.

\section{Corresponding author}

Yash Chawla can be contacted at: yash.chawla@pwr.edu.pl

For instructions on how to order reprints of this article, please visit our website: www.emeraldgrouppublishing.com/licensing/reprints.htm Or contact us for further details: permissions@emeraldinsight.com 